\title{
Synthesis and Physical Properties of Several Acetylenic Hydrocarbons
}

\author{
Philip Pomerantz, Abraham Fookson, ${ }^{1}$ Thomas W. Mears, Simon Rothberg, ${ }^{2}$ and Frank L. \\ Howard
}

As a part of researches conducted on hydrocarbons as jet-fuel components under the auspices of the National Advisory Committee for Aeronautics, a number of acetylenic hydrocarbons and their intermediates have been prepared. The details of these syntheses and the physical constants measured on the compounds are presented.

\section{Introduction}

The work described herein is the continuation of hydrocarbon research conducted at the Bureau since 1937 under the administrative sponsorship of the National Advisory Committee for Aeronautics. Previous papers $[5,12]^{3}$ have described the preparation and physical properties of a number of aliphatic hydrocarbons and their intermediates; these were used mainly in researches on the detonation proper-

\footnotetext{
1 Present address, Frankl Photographic Services, Washington, D. C.

2 Present address, National Institutes of Health, Bethesda, Md

3 Figures in brackets indicate the literature references at the end of this paper.
}

ties of fuels for reciprocating engines. More recently, attention has been directed to fuels for reaction engines. The emphasis at the Bureau was thereby shifted to hydrocarbons useful in investigations of basic problems in jet-fuel combustion. The hydrocarbons selected for synthesis were alkynes, alkadiynes, and an alkenyne, and were chosen in order to ascertain the effects of structure on flame speed and other properties. These compounds and the intermediates used in their syntheses are listed in table 1 , in which are enumerated the physical constants of the material prepared, the purities of selected hydrocarbons, and the melting points of the mercury derivative of the 1-acetylenes [6].

TABLE 1. Physical properties of compounds prepared

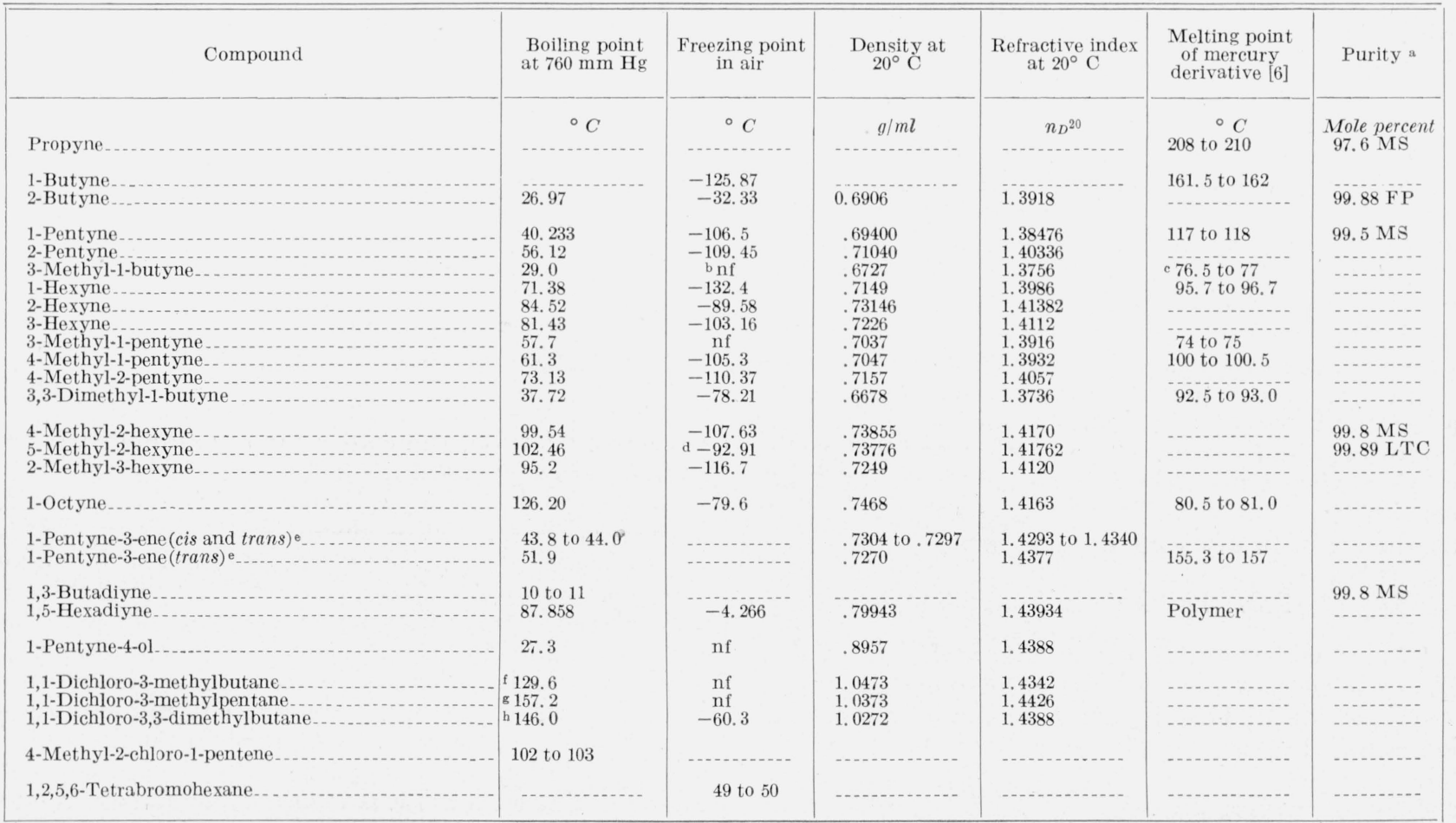

a FP, purity from freezing curve analysis [16]; LTC, purity by low-temperature calorimetry (by G. T. Furukawa, Thermodynamics Section [4]); MS, purity by mass spectrometry (by V. H. Dibeler and F. L. Mohler, Mass Spectrometry Section.)

$\mathrm{b}$ nf is nonfreezing, glassy at low temperatures.

c On freshly prepared material. After standing for 4 days, material became yellow and did not melt at $150^{\circ} \mathrm{C}$. d Triple point, measured in calorimeter by G. T. Furukawa of Thermodynamics Section. Molar heat of fusion $=10,600$ joules.

e cis and trans designations from infrared spectrometry, performed and inter. preted by F. A. Smith and J. E. Stewart.

f $90^{\circ} \mathrm{C}$ at $240 \mathrm{~mm}$.

g $92^{\circ} \mathrm{C}$ at $100 \mathrm{~mm}$. 


\section{Equipment}

\subsection{Reaction Vessels}

Large-scale reactions were carried out in a commercial 50-gal stainless-steel reaction vessel designed to permit any jacket temperature from $5^{\circ}$ to $150^{\circ}$ $\mathrm{C}$ to be maintained. This kettle is described in a previous publication [5].

For experimental runs and for small-scale work, a 5-gal brass kettle was used. This was made of 12 -in. brass tubing with a sheet-brass bottom brazed into place and a removable flanged top to facilitate emptying and cleaning. The top was equipped with openings for stirrer, addition vessel, reflux condenser, and observation hole, and was held in place by means of C-clamps and sealed by means of a neoprene gasket pressed between the flanges. This reactor was of sufficiently small size to allow immersion in a bath for heating or cooling, as necessary. Because of the relatively high heat conductivity of the metal, this apparatus permitted highly exothermic reactions, such as halide condensations (see sec. 3.4), to be run with appreciable savings of time and much greater safety than prevails with the use of glass equipment of equal capacity. Glass equipment was used only for very small-scale preliminary reactions.

For reactions using liquid ammonia as a solvent (see sec. 3.2 and 3.3), a 10-gal stainless-steel reaction vessel was installed. This was jacketed for temperature control and equipped with appropriate valves and flanged openings; on the bottom was a 2-in. drain valve, on the top were openings for a 2 -in. peephole, gas inlet, and reflux condenser. The peephole was normally stoppered, but when necessary, it could be used for observation of the reaction or addition of reagents. Acetylene and other gases were introduced through a $1 / 4$-in. steel pipe brazed through a flange and extending almost to the bottom of the vessel. The condenser consisted of a 30-gal open-top insulated cylinder, through which passed two intertwined coils made of $20-\mathrm{ft}$ lengths of $3 / 4$-in. steel pipe welded into a 1 -in. tee at the bottom. The 1-in. tee connected to a sight-glass for observation of reflux and thence to the kettle. Stirring was effected by means of a built-in stirrer driven by an explosion-proof motor. The kettle was insulated on all sides with a 6 -in. layer of ground cork. When in continuous operation, it was necessary to fill the condenser with dry ice only at 8-hr intervals.

\subsection{Distillation Equipment}

There were seven stills available for this work. These were used for purification of reagents, for the fractionation of final hydrocarbons and some of the intermediates, and have been described previously [5]. For convenience, the salient features of each are listed in table 2.
TABLE 2 .

\begin{tabular}{|c|c|c|c|c|}
\hline Still & Type & Size & Packing & Pot capacity \\
\hline $5 \ldots$ & $\begin{array}{l}\text { Total reflux vari- } \\
\text { able takeoff. }\end{array}$ & $\begin{array}{c}\mathrm{cm} \\
150 \text { by } 2.2 . .\end{array}$ & $\begin{array}{l}3 / 32 \text {-in. stainless } \\
\text { steel helices } \\
\text { from } 0.010 \text {-in. } \\
\text { wire. }\end{array}$ & $\begin{array}{c}m l \\
200 \text { to } 5,000 .\end{array}$ \\
\hline $17-$ & $\begin{array}{l}\text { Podbielniak Hy- } \\
\text { percal. }\end{array}$ & 127 by $0.8 \ldots$ & $\begin{array}{l}16 \text {-in, glass nelices } \\
\text { Heli-grid }\end{array}$ & 250 to 5,000 . \\
\hline & $\begin{array}{l}\text { Total reflux vari- } \\
\text { able takeoff. }\end{array}$ & 120 by $3.5 \ldots$ & $3 / 16$-in. glass helices & $\begin{array}{l}250 \text { to } 5,000 . \\
22,000 \text {. }\end{array}$ \\
\hline $22 \ldots$ & $\ldots d o \ldots \ldots \ldots \ldots$ & 35 by $2.5_{-}$ & $\begin{array}{l}\text { 3/32-in. stainless } \\
\text { steel helices } \\
\text { from } 0.010 \text {-in. } \\
\text { wire. } \\
\text { 1/8-in. glass helices. }\end{array}$ & 500 to 5,000 . \\
\hline
\end{tabular}

\section{Methods and Technique}

\subsection{Preparation of Grignard Reagents}

The Grignard reagents necessary for some of the syntheses were prepared in the 50-gal stainless-steel kettle according to the methods used previously [5]. In all cases the Grignard reagent was then reacted in place.

\subsection{Preparation of Sodium Acetylide}

For the preparation of many of the acetylene homologs, the starting material was monosodium or disodium acetylide. The flow sheets of the several synthetic schemes, using these compounds as starting materials, are given as methods $\mathrm{A}$ to $\mathrm{C}$ in table 3 , in which are enumerated the several different synthetic routes used in this work and the compounds prepared thereby. The technique of preparing sodium acetylide was adapted from that used by K. W. Greenlee and his associates at Ohio State University, Columbus, Ohio. These sodium acetylides were conveniently prepared in the 10-gal stainless-steel reactor and alkylated in place to the desired alkyne. A typical preparation of 60 moles of monosodium acetylide is described below.

About $10 \mathrm{~kg}$ of commercial anhydrous ammonia was added in the liquid phase to the reactor through the gas-inlet tube, the cold refluxing ammonia being sufficient to cool the pot. Then $15 \mathrm{~g}$ of ferric chloride was added deftly in 3 portions through the peephole. The reaction was quite violent, and after the reflux had subsided, about $60 \mathrm{~g}$ of sodium cut in small pieces was added. After the sodium had dissolved, a stream of dry air was passed through the gas-inlet tube for about $1 \frac{1}{2} \mathrm{~min}$, in order to form a catalyst, which would be effective in converting the sodium into the amide rapidly. Sodium cut into approximately $1 / 2-i n$. cubes was then added in portions with stirring until a total of $1,389 \mathrm{~g}$ (60 g-atoms) was added The reaction was vigorous, and a continuous 
Method A. Alkylation of monosodium acetylide:

$$
\begin{gathered}
\mathrm{Na} \underset{\mathrm{NH}_{3}}{\stackrel{\text { liquid }}{\longrightarrow}} \mathrm{NaNH}_{2} \stackrel{\mathrm{CH} \equiv \mathrm{CH}}{\longrightarrow} \mathrm{NaC} \equiv \mathrm{CH} \stackrel{\mathrm{RX} *}{\longrightarrow} \mathrm{RC} \equiv \mathrm{CH} \\
\mathrm{R}=\mathrm{CH}_{3}, \mathrm{C}_{2} \mathrm{H}_{5}, n-\mathrm{C}_{3} \mathrm{H}_{7}, n-\mathrm{C}_{4} \mathrm{H}_{9}, n-\mathrm{C}_{6} \mathrm{H}_{13} .
\end{gathered}
$$

Method B. Symmetrical alkylation of disodium acetylide:

$$
\begin{gathered}
\underset{\mathrm{Na} \underset{\mathrm{NH}_{3}}{\mathrm{liquid}}}{\longrightarrow} \mathrm{NaNH}_{2} \stackrel{\mathrm{CH} \equiv \mathrm{CH}}{\longrightarrow} \mathrm{NaC} \equiv \mathrm{CNa} \stackrel{\mathrm{RX}}{\longrightarrow} \mathrm{RC} \equiv \mathrm{CR} \\
\mathrm{R}=\mathrm{CH}_{3}, \mathrm{C}_{2} \mathrm{H}_{5}
\end{gathered}
$$

Method C. Unsymmetrical alkylation of acetylene (in situ):

$$
\begin{gathered}
\underset{\mathrm{NH}_{3}}{\mathrm{Naquid}} \mathrm{NaNH}_{2} \stackrel{\mathrm{CH} \equiv \mathrm{CH}}{\longrightarrow} \mathrm{NaC} \equiv \mathrm{CH} \stackrel{\mathrm{RX}}{\longrightarrow} \mathrm{RC} \equiv \mathrm{CH} \underset{\mathrm{NaNH}_{2}}{\stackrel{\text { powdered }}{\longrightarrow}} \mathrm{RC} \equiv \mathrm{CNa} \stackrel{\mathrm{R}^{\prime} \mathrm{X}}{\longrightarrow} \mathrm{RC} \equiv \mathrm{CR}^{\prime} \\
\mathrm{R}=\mathrm{C}_{2} \mathrm{H}_{5}, n-\mathrm{C}_{3} \mathrm{H}_{7} \\
\mathrm{R}^{\prime}=\mathrm{CH}_{3}
\end{gathered}
$$

Method D. Alkylation of 1-alkynes:

$$
\begin{gathered}
\underset{\mathrm{Na} \underset{\mathrm{NH}_{3}}{\longrightarrow} \mathrm{NaNH}}{\stackrel{\mathrm{RC}}{\longrightarrow} \mathrm{CH}} \mathrm{RC} \equiv \mathrm{CNa} \stackrel{\mathrm{R}^{\prime} \mathrm{X}}{\longrightarrow} \mathrm{RC} \equiv \mathrm{CR}^{\prime} \\
\mathrm{R}=i-\mathrm{C}_{3} \mathrm{H}_{7}, i-\mathrm{C}_{4} \mathrm{H}_{9}, s-\mathrm{C}_{4} \mathrm{H}_{9} \\
\mathrm{R}^{\prime}=\mathrm{CH}_{3}, \mathrm{C}_{2} \mathrm{H}_{5}
\end{gathered}
$$

Method E: Vinylation and dehydrohalogenation reactions:

$$
\begin{gathered}
\mathrm{RCl} \stackrel{\mathrm{CH}_{2}=\mathrm{CHCl}}{\longrightarrow} \mathrm{RCH}_{2} \mathrm{CHCl}_{2} \underset{90^{\circ}-100^{\circ} \mathrm{C}}{\stackrel{\mathrm{NaNH}_{2}}{\longrightarrow}} \mathrm{RC} \equiv \mathrm{CH} \\
\mathrm{R}=i-\mathrm{C}_{3} \mathrm{H}_{7}, s-\mathrm{C}_{4} \mathrm{H}_{9}, t-\mathrm{C}_{4} \mathrm{H}_{9}
\end{gathered}
$$

Method F. Alkylation and dehydrohalogenation reactions:

$$
\begin{aligned}
& \mathrm{RMgX}+\mathrm{CH}_{2}=\mathrm{CClCH}_{2} \mathrm{Cl} \longrightarrow \mathrm{RCH}_{2} \mathrm{CCl}=\mathrm{CH}_{2} \underset{150^{\circ} \mathrm{C}}{\stackrel{\mathrm{NaNH}_{2}}{\longrightarrow}} \mathrm{RCH}_{2} \mathrm{C} \equiv \mathrm{CH} \\
& \mathrm{R}=i-\mathrm{C}_{3} \mathrm{H}_{7}
\end{aligned}
$$

Method G. Dehydrohalogenation and isomerization reactions:

$$
\mathrm{HOCH}(\mathrm{R}) \mathrm{C} \equiv \mathrm{CCH}(\mathrm{R}) \mathrm{OH} \stackrel{\mathrm{SOCl}_{2}}{\longrightarrow} \mathrm{ClCH}(\mathrm{R}) \mathrm{C} \equiv \mathrm{CH}(\mathrm{R}) \mathrm{Cl} \stackrel{\mathrm{KOH}}{\longrightarrow} \mathrm{RC} \equiv \mathrm{CC} \equiv \mathrm{CR}
$$

Method H. Halogenation and dehydrohalogenation:

$$
\mathrm{R}=\mathrm{H}
$$

$$
\mathrm{CH}_{2}=\mathrm{CHCH}_{2} \mathrm{CH}_{2} \mathrm{CH}=\mathrm{CH}_{2} \stackrel{\mathrm{Br}_{2}}{\longrightarrow} \mathrm{CH}_{2} \mathrm{BrCHBrCH}_{2} \mathrm{CH}_{2} \mathrm{CHBrCH}_{2} \mathrm{Br} \underset{\mathrm{NH}_{3}(\mathrm{l})}{\longrightarrow} \mathrm{NH} \equiv \mathrm{CH}-\mathrm{CH}_{2} \mathrm{CH}_{2} \mathrm{C} \equiv \mathrm{CH}_{2}
$$

Method I. Alkynation and dehydration reactions:

$$
\begin{aligned}
& \mathrm{RCHCH}_{2} \\
& \mathrm{Na} \underset{\mathrm{NH}_{3}}{\stackrel{\text { liquid }}{\longrightarrow}} \mathrm{NaNH}_{2} \stackrel{\mathrm{CH} \equiv \mathrm{CH}}{\longrightarrow} \mathrm{NaCC} \equiv \mathrm{CH} \underset{-33^{\circ} \mathrm{C}}{\longrightarrow} \mathrm{OH} \equiv \mathrm{CCH}_{2} \mathrm{CH}(\mathrm{R}) \mathrm{OH} \stackrel{p \text {-toluene sulfonyl }}{\text { chloride }} \\
& \mathrm{CH} \equiv \mathrm{CCH}_{2} \mathrm{CH}(\mathrm{R})-\mathrm{OSO}_{2} \mathrm{C}_{6} \mathrm{H}_{4} \mathrm{CH}_{3}(p) \underset{110^{\circ} \mathrm{C}}{\stackrel{\mathrm{KOH}}{\longrightarrow}} \mathrm{CH} \equiv \mathrm{C}-\mathrm{CH}=\mathrm{CH}-\mathrm{R} \\
& \mathrm{R}=\mathrm{CH}_{3}
\end{aligned}
$$


stream of hydrogen was evolved. The solution was then stirred for $2 \mathrm{hr}$ before the addition of acetylene. In several cases the conversion of sodium to sodium amide was extremely slow, the sodium merely dissolving in the ammonia. This was evidenced by the persistent, intense blue color of the liquid. In such cases the solution was permitted to stand overnight, or until it attained a characteristic black hue and the blue coloration was completely gone.

Commercial acetylene gas was then passed into the sodium-amide solution through the gas-inlet tube after it had passed through a sulfuric acid scrubber to remove entrained acetone. Disodium acetylide was formed first and imparted a milky-white appearance to the liquid. For the preparation of disodium acetylide, the gas addition was stopped when the molal ratio of acetylene to sodium was one-half. Upon continued addition of acetylene, the disodium salt was converted to the monosodium acetylide, and as the theoretical quantity for monosodium-acetylide formation was approached, the color of the solution regained its black appearance. Thus, from $60 \mathrm{~g}$ atoms of original sodium, 30 moles of disodium acetylide were formed with $780 \mathrm{~g}$ of acetylene, whereas the addition of $1,560 \mathrm{~g}$ of acetylene caused formation of 60 moles of monosodium acetylide.

\subsection{Alkylation Reactions}

The alkylation of the sodium acetylides and their homologs was carried out in the 10-gal stainless-steel reactor. Because of the variation in the technique, representative alkylations illustrating methods $\mathrm{A}$ to $\mathrm{D}$ in table 3 are described below. A résumé of the preparation of each acetylene made thereby is given in table 4 .

(a) Method A. Propyne was prepared in 65-percent yield by treatment of monosodium acetylide with dimethyl sulfate in liquid ammonia. Sixty theoretical moles of monosodium acetylide was prepared from $1.70 \mathrm{~kg}$ of acetylene (65 moles), $1.61 \mathrm{~kg}$ of sodium (70 g-atoms), and $18 \mathrm{~g}$ of ferric chloride in $11 \mathrm{~kg}$ of liquid ammonia, using a modification of the previously described method (see sec. 3.2). Because of the difficulty in separating acetylene from propyne, care had to be taken to avoid an excess of acetylene; consequently, only enough acetylene was added to make 60 moles of monosodium acetylide and 5 moles of disodium acetylide. In this case, the 2-butyne formed as a by-product from the disodium acetylide present offered no problem in the purification step.

To this acetylide solution was added $8.8 \mathrm{~kg}$ (70 moles) of dimethylsulfate over a period of $3 \mathrm{hr}$. The reaction was quite vigorous but easily controllable. The mixture was stirred overnight, after which it was treated with 11.5 liters of water. The condenser was then blocked off at the sight glass, and a delivery tube attached through the peephole flange. The evolved gas was passed through a train consisting of a water trap with a constant-level continuous-flow siphon, cold 10-percent sulfuric acid, a calcium-chloride drying tower, a dry-ice condenser, and was caught in a chilled steel cylinder containing a small amount of acetone. The product from two runs was fractionated in column 19 to recover 3.25 $\mathrm{kg}$ (81 moles) of purified 1-propyne (65-percent yield).

(b) Method B. 2-butyne was prepared by the reaction of dimethylsulfate with disodium acetylide in liquid ammonia. Forty moles of disodium acetylide were prepared from 1,840 $\mathrm{g}$ of sodium ( $80 \mathrm{~g}$-atoms), $1.05 \mathrm{~kg}$ (40 moles) of acetylene, and $20 \mathrm{~g}$ of ferric chloride in $14.5 \mathrm{~kg}$ of liquid ammonia, by the technique previously described (see sec. 3.2). To this mixture was added $10.6 \mathrm{~kg}$ (84 moles) of dimethylsulfate over a period of $6 \mathrm{hr}$; the reaction was vigorous, but controllable. The solution was stirred for $16 \mathrm{hr}$, and the 2-butyne was recovered in the same manner used for propyne. In this case, however, most of the 2-butyne condensed in the chilled dilute sulfuric acid, and was distilled from this flask through a calcium-chloride tower into a steel bomb by heating the flask with an electric heating mantle. This run

TABLE 4. Alkynes by alkylation

\begin{tabular}{|c|c|c|c|c|c|c|c|c|c|c|c|}
\hline \multirow{2}{*}{ Hydrocarbon } & \multirow{2}{*}{$\begin{array}{l}\text { Prepara- } \\
\text { tive } \\
\text { method }\end{array}$} & \multicolumn{4}{|c|}{ Reactants } & \multicolumn{4}{|c|}{ Alkylation agents } & \multirow{2}{*}{\multicolumn{2}{|c|}{ Product yield }} \\
\hline & & $\mathrm{Na}$ & $\mathrm{C}_{2} \mathrm{H}_{2}$ & $\mathrm{FeCl}_{3}$ & $\mathrm{NH}_{3}(1)$ & $\mathrm{RX}$ (first & & $\mathrm{R}^{\prime} \mathrm{X}$ & ond) & & \\
\hline Propyne_... & A & $\begin{array}{l}\text { g-atoms } \\
70\end{array}$ & $\begin{array}{c}\text { Moles } \\
65\end{array}$ & $\begin{array}{c}g \\
18\end{array}$ & $\begin{array}{l}\mathrm{kg} \\
11.0\end{array}$ & $\begin{array}{c}\text { Compound } \\
\mathrm{CH}_{3} \mathrm{Br}_{\ldots} \ldots . . .\end{array}$ & $\begin{array}{l}\text { Moles } \\
60\end{array}$ & Compound & Moles & $\begin{array}{l}\text { Moles } \\
40.5\end{array}$ & $\begin{array}{l}\text { Percent } \\
\quad 65\end{array}$ \\
\hline $\begin{array}{l}\text { 1-Butyne } \\
\text { 2-Butyne }\end{array}$ & $\begin{array}{l}\mathrm{A} \\
\mathrm{B}\end{array}$ & $\begin{array}{l}70 \\
80\end{array}$ & $\begin{array}{l}65 \\
40\end{array}$ & $\begin{array}{l}18 \\
20\end{array}$ & $\begin{array}{l}11.0 \\
14.5\end{array}$ & $\begin{array}{l}\left(\mathrm{C}_{2} \mathrm{H}_{5}\right)_{2} \mathrm{SO}_{4} \\
\mathrm{CH}_{3} \mathrm{Br}\end{array}$ & $\begin{array}{l}60 \\
84\end{array}$ & & & $\begin{array}{l}43.7 \\
17.0\end{array}$ & $\begin{array}{l}67 \\
42\end{array}$ \\
\hline $\begin{array}{l}\text { 1-Pentyne } \\
\text { 2-Pentyne }\end{array}$ & $\stackrel{\mathrm{A}}{\mathrm{C}}$ & $\begin{array}{l}21 \\
45\end{array}$ & $\begin{array}{l}\text { (a) } \\
45\end{array}$ & ${ }_{12}^{5.5}$ & $\begin{array}{l}3.5 \\
9.1\end{array}$ & $\begin{array}{l}n-\mathrm{C}_{3} \mathrm{H}_{7} \mathrm{Cl} \\
\mathrm{C}_{2} \mathrm{H}_{3} \mathrm{Br}\end{array}$ & $\begin{array}{l}21 \\
45\end{array}$ & $\mathrm{CH}_{3} \mathrm{Br}$ & $\mathrm{b} 48$ & $\begin{array}{r}7.4 \\
36.3\end{array}$ & $\begin{array}{l}35 \\
81\end{array}$ \\
\hline $\begin{array}{l}\text { 1-Hexyne } \\
\text { 2-Hexyne } \\
\text { 3-Hexyne } \\
\text { 4-Methyl-2-pentyne }\end{array}$ & $\begin{array}{l}\text { A } \\
\text { C } \\
\text { B } \\
\text { D }\end{array}$ & $\begin{array}{l}60 \\
45 \\
80 \\
63\end{array}$ & $\begin{array}{l}60 \\
45 \\
40 \\
(\mathrm{~d})\end{array}$ & $\begin{array}{l}15 \\
12 \\
20 \\
15\end{array}$ & $\begin{array}{r}10.3 \\
9.1 \\
10.0 \\
10.0\end{array}$ & $\begin{array}{l}n-\mathrm{C}_{4} \mathrm{H}_{9} \mathrm{Br} \\
n-\mathrm{C}_{3} \mathrm{H}_{7} \mathrm{Br} \\
\left(\mathrm{C}_{2} \mathrm{H}_{5}\right)_{2} \mathrm{SO}_{4} \\
\left(\mathrm{CH}_{3}\right)_{2} \mathrm{SO}_{4} \ldots\end{array}$ & $\begin{array}{l}60 \\
45 \\
80.5 \\
63\end{array}$ & $\left(\mathrm{CH}_{3}\right)_{2} \mathrm{SO}_{4}$ & b 48.5 & $\begin{array}{l}28.8 \\
27 \\
25.6 \\
24\end{array}$ & $\begin{array}{r}48 \\
60 \\
\mathrm{e} 64 \\
42\end{array}$ \\
\hline $\begin{array}{l}\text { 4-Methyl-2-hexyne } \\
\text { 5-Methyl-2-hexyne } \\
\text { 2-Methyl-3-hexyne.. }\end{array}$ & $\begin{array}{l}\mathrm{D} \\
\mathrm{D} \\
\mathrm{D}\end{array}$ & $\begin{array}{l}40 \\
35 \\
48\end{array}$ & $\begin{array}{l}\text { (e) } \\
\text { (g) } \\
\text { (h) }\end{array}$ & $\begin{array}{r}9 \\
12 \\
12\end{array}$ & $\begin{array}{l}7.5 \\
9.1 \\
9.1\end{array}$ & $\begin{array}{l}\mathrm{CH}_{3} \mathrm{Br} \\
\mathrm{CH}_{3} \mathrm{Br} \\
\mathrm{C}_{2} \mathrm{H}_{5} \mathrm{Br}\end{array}$ & $\begin{array}{l}40 \\
40 \\
50\end{array}$ & & & $\begin{array}{l}25 \\
28.4 \\
38.6\end{array}$ & $\begin{array}{r}{ }^{\mathrm{f}} 69 \\
81 \\
80\end{array}$ \\
\hline 1-Octyne & A & 30 & 30 & 7 & 5.5 & $n-\mathrm{C}_{6} \mathrm{H}_{13} \mathrm{Br} \ldots$ & 30 & & & 11.2 & 38 \\
\hline
\end{tabular}

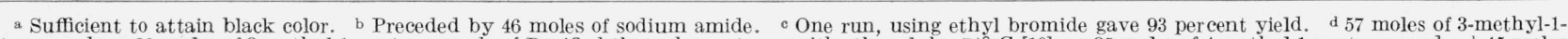

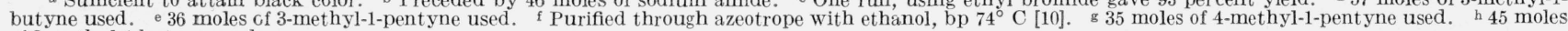
of 3-methyl-1-butyne used. 
produced a total of $0.91 \mathrm{~kg}$ (17 moles) of crude 2 -butyne; yield, 42 percent. The crude was fractionated through column 19 to yield 2-butyne with the properties listed in table 1.

(c) Method C. 2-pentyne was prepared by the treatment of monosodium acetylide with ethyl bromide in liquid ammonia, followed by the reaction of methyl bromide with the sodium derivative (formed in situ) of the resulting 1-butyne. Monosodium acetylide (45 moles) was formed from 1,035 $\mathrm{g}$ (45 g-atoms) of sodium, $1.17 \mathrm{~kg}$ (45 moles) of acetylene and $12 \mathrm{~g}$ of ferric chloride in $9.1 \mathrm{~kg}$ of ammonia by the usual technique (see sec. 3.2). To this solution was added $4.91 \mathrm{~kg}$ of ethyl bromide (45 moles) over a period of $2 \frac{1}{2} \mathrm{hr}$, during which the reaction was quite vigorous. After the addition was completed, the reaction mixture was stirred for $1 \frac{112}{2}$ $\mathrm{hr}$ before adding $1.82 \mathrm{~kg}$ of commercial sodium amide over a period of $45 \mathrm{~min}$. The solution was stirred for $1 \mathrm{hr}$, and then $4.58 \mathrm{~kg}$ of methyl bromide was added to the reaction in the liquid phase. The mixture became quite viscous and was allowed to stand overnight. The next morning it had solidified and the stirrer would not operate. To loosen it, $2.7 \mathrm{~kg}$ of liquid ammonia was added. This was followed by 3.8 liters of isooctane ${ }^{4}$ as solvent and 15 liters of water. There was no vigouous reflux during this decomposition. The organic layer was separated, washed twice with cold water, once with dilute hydrochloric acid, and dried over anhycirous sodium carbonate.

On distillation there was obtained $2.47 \mathrm{~kg}$ (36.3 moles) of pure 2-pentyne with the properties listed in table 1. This recovery corresponds to a yield of 81 percent.

(d) Method D. 5-methyl-2-hexyne was formed by the methylation of 4-methyl-1-pentyne prepared by method E. To a solution of sodium amide prepared in the usual way from $805 \mathrm{~g}$ ( $35 \mathrm{~g}$-atoms) of sodium, $12 \mathrm{~g}$ of ferric chloride, and $9.1 \mathrm{~kg}$ of ammonia, was added $2.87 \mathrm{~kg}$ (35 moles) of 4-methyl-1-pentyne. The addition took $1 \mathrm{hr}$ and did not cause very vigorous refluxing. After $2 \mathrm{hr}$ of stirring, $3.64 \mathrm{~kg}$ (38 moles) of methyl bromide was added rapidly through the gas-inlet tube. The reaction mixture was stirred overnight, after which it was treated with 19 liters of water. The organic layer was filtered and washed three times with water, and then dried over

${ }^{4}$ Isooctane is the trivial name for 2,2,4-trimethylpentane. anhydrous sodium carbonate. Distillation of the crude through column 6 yielded $2.73 \mathrm{~kg}$ of material, boiling at $102^{\circ}$ to $103^{\circ} \mathrm{C}$ (yield, 81 percent). Redistillation in still 19 yielded a product with the properties listed in table 1.

\subsection{Preparation of Halides-Methods E to H}

Direct alkylation of sodium acetylide is not successful with branched-chain adducts. Therefore, it was necessary to prepare branched acetylenes by dehydrohalogenation of appropriate halogen compounds [17]. Several dihalides used in method E (see table 3) were prepared by adaptations of the vinylation method of Schmerling [15]; one chlorolefin was prepared by the Grignard reaction [9]. Dehydrohalogenation reactions were also used for the syntheses of two diacetylenes (methods $\mathrm{G}$ and $\mathrm{H}$ ). The halides for these were made by chlorination of a polyalcohol and by addition of bromine to a diolefin. In table 5 are given data on typical syntheses of the intermediate halides used in preparing 3-methyl-1-butyne, 3-methyl-1-pentyne, 3,3dimethyl-1-butyne, 4-methyl-1-pentyne, 1,3-butadiyne, and 1,5-hexadiyne, respectively, some of which were used in additional preparations utilizing alkylation techniques (see table 4).

(a) Halides for method $E$. Inasmuch as the quantities involved in these syntheses were many times greater than those used by Schmerling, it was necessary to develop techniques for the addition of reagents and control of the reaction in order to assure adequate yield. Typical of the several vinylation reactions is the preparation of 1,1-dichloro3-methylbutane, which proceeds according to the reaction

$$
i-\mathrm{C}_{3} \mathrm{H}_{7} \mathrm{Cl}+\mathrm{CH}_{2}=\mathrm{CHCl} \frac{\mathrm{AlCl}_{3}}{-30^{\circ} \text { to }-40^{\circ} \mathrm{C}}\left(\mathrm{CH}_{3}\right)_{2} \mathrm{CHCH}_{2} \mathrm{CHCl}_{2} \text {. }
$$

To the 5-gal brass reactor equipped with stirrer, condenser cooled to $-78^{\circ} \mathrm{C}$, thermometer, and inlet tube were added $3.92 \mathrm{~kg}$ (50 moles) of isopropyl chloride and $340 \mathrm{~g}$ ( 2.5 moles) of aluminum chloride. Effervescence and darkening of the liquid began immediately upon this addition; the former ceased after a short time and did not resume during the subsequent addition of vinyl chloride. After the initial heat of reaction had been dissipated, the contents of the pot was cooled to $-30^{\circ} \mathrm{C}$, and $3,286 \mathrm{~g}$ (53 moles)

TABLE 5. Halide intermediates

\begin{tabular}{|c|c|c|c|c|c|c|}
\hline Compound prepared & Method & \multicolumn{3}{|c|}{ Reactants } & \multicolumn{2}{|c|}{ Yields } \\
\hline $\begin{array}{l}\left(\mathrm{CH}_{3}\right)_{2} \mathrm{CHCH}_{2} \mathrm{CHCl}_{2} \\
\mathrm{CH}_{3} \mathrm{CH}_{2} \mathrm{CH}\left(\mathrm{CH}_{3}\right) \mathrm{CH}_{2} \mathrm{CHCl}_{2} \\
\left(\mathrm{CH}_{3}\right)_{3} \mathrm{CCH}_{2} \mathrm{CHCl}_{2} \mathrm{CH}_{2} \\
\left(\mathrm{CH}_{3}\right)_{2} \mathrm{CHCH} \mathrm{CH}_{2} \mathrm{Cl}=\mathrm{CH}_{2} \\
\mathrm{ClCH}_{2} \mathrm{C} \mathrm{CH}_{2} \mathrm{CH}_{2} \mathrm{Cl} \\
\mathrm{CH}_{2} \mathrm{BrCH} \mathrm{CHCH}{ }_{2} \mathrm{CH}_{2} \mathrm{CHBrCH} \mathrm{Br}_{-}\end{array}$ & $\begin{array}{l}\mathrm{E} \\
\mathrm{E} \\
\mathrm{E} \\
\mathrm{F} \\
\mathrm{G} \\
\mathrm{H}\end{array}$ & $\begin{array}{l}\left(\mathrm{CH}_{3}\right)_{2} \mathrm{CHCl}(50 \text { moles }) \\
\mathrm{CH}_{3} \mathrm{CH}_{2} \mathrm{C}\left(\mathrm{CH} \mathrm{CH}_{3}\right) \mathrm{Cl}(60 \text { moles }) \\
\left(\mathrm{CH}_{3}\right)_{3} \mathrm{Cl}(50 \text { moles }) \\
\mathrm{CH}_{2}=\mathrm{CClCH}_{2} \mathrm{Cl}(153 \text { moles }) \\
\mathrm{HOCH}_{2} \mathrm{C} \equiv \mathrm{CCH}_{2} \mathrm{OH}(4.7 \text { moles })^{-} \\
\mathrm{CH}_{2}=\mathrm{CHCH} \mathrm{CH}_{2} \mathrm{CH}_{2} \mathrm{CH}=\mathrm{CH}_{2}(24 \\
\text { moles }) .\end{array}$ & $\begin{array}{l}\mathrm{CH}_{2}=\mathrm{CHCl}(53 \text { moles }) \ldots \\
\mathrm{CH}_{2}=\mathrm{CHCl}(60 \text { moles }) \ldots \\
\mathrm{CH}_{2}=\mathrm{CHCl}(53 \mathrm{moles}) \\
\mathrm{a}\left(\mathrm{CH}_{3}\right){ }_{2} \mathrm{CHMgCl} \\
\mathrm{SOCl}_{2}(8.4 \mathrm{moles}) \\
\mathrm{Br}_{2}(48 \mathrm{moles})\end{array}$ & $\begin{array}{l}\mathrm{AlCl} l_{3}(340 \mathrm{~g}) \\
\mathrm{AlCl}_{3}(351 \mathrm{~g}) \ldots \ldots \\
\mathrm{AlCl}_{3}(454 \mathrm{~g}) \ldots \ldots\end{array}$ & $\begin{array}{c}\text { Moles } \\
36 \\
40.7 \\
35 \\
70 \\
3.3 \\
20.4\end{array}$ & $\begin{array}{r}\text { Percent } \\
72 \\
68 \\
70 \\
\text { b59 } \\
70 \\
84\end{array}$ \\
\hline
\end{tabular}

a Prepared from 170 moles of isopropylchloride, $170 \mathrm{~g}$-atoms of magnesium in 52 liters of either.

b Based on dichloride consumed. 
of vinyl chloride was bubbled rapidly into the stirred solution. This reaction is extremely exothermic, and rapid removal of heat is essential to prevent its becoming violent. In this case the addition required about $2 \mathrm{hr}$ with the temperature at $-30^{\circ}$ to $-40^{\circ} \mathrm{C}$. The solution was stirred for 90 min after the addition was completed; the entire brownish reaction mixture was then poured onto cracked ice. After the colors of the aluminum-chloride complexes disappeared, a yellow liquid, heavier than water, remained. About $2,000 \mathrm{ml}$ of ligroin was added as solvent; the resulting organic solution was washed once with dilute sodium carbonate and twice with water, dried over anhydrous sodium carbonate, and fractionated through column 6. After the ligroin forerun, there was collected a main product of $1,600 \mathrm{ml}$, boiling $127^{\circ}$ to $130.5^{\circ} \mathrm{C}$. The yield was 72 percent.

(b) Halide for method $F$. The chloroolefin used in method $\mathrm{F}$ was prepared by the reaction of isopropylmagnesium chloride on 2,3-dichloro-1-propene, according to the equation

$$
\begin{aligned}
& \left(\mathrm{CH}_{3}\right)_{2} \mathrm{CHMgCl}+\mathrm{CH}_{2} \mathrm{Cl}-\mathrm{CCl}=\mathrm{C} \mathrm{H}_{2} \longrightarrow \\
& \left(\mathrm{CH}_{3}\right)_{2} \mathrm{CH}-\mathrm{CH}_{2}-\underset{\mathrm{Cl}}{\mathrm{C}}=\mathrm{CH}_{2} \text {. }
\end{aligned}
$$

Isopropylmagnesium chloride was prepared in the usual manner from $13.4 \mathrm{~kg}$ ( 170 moles) of isopropyl chloride, $4.09 \mathrm{~kg}$ of magnesium turnings (170 gatoms), and 52 liters of anhydrous ether in the 50 -gal stainless-steel kettle. To this stirred solution $16.95 \mathrm{~kg}$ (153 moles) of 2,3-dichloro-1-propene dissolved in 16 liters of ether was added over a period of 3 days. At the end of this time, the reaction mixture was treated in the usual manner with $5.45 \mathrm{~kg}$ of concentrated hydrochloric acid in 75 liters of water. The ether layer was washed four times with water and dried over anhydrous sodium carbonate. On distillation through column 6 , the organic layer yielded $3.82 \mathrm{~kg}$ (34 moles) of unreacted 2,3 -dichloro-1-propene (bp $88^{\circ}$ to $96^{\circ} \mathrm{C}$ ) and 8.27 $\mathrm{kg}(70$ moles) of 4-methyl-2-chloro-1-pentene (bp $100^{\circ}$ to $104^{\circ} \mathrm{C}$ ). The yield, based on material consumed, was 59 percent.

(c) Halide for method $G$. The 1,4-dichloro-2 butyne used in this work was prepared by reaction of commercial 1,4-dihydroxy-2-butyne with thionyl chloride [1]. To a 5-liter flask fitted with stirrer, dropping funnel, and reflux condenser, and containing $400 \mathrm{~g}$ of pulverized 1,4-butynediol was added 1,000 $\mathrm{g}$ of pure thionyl chloride; during this addition, the temperature of the mixture decreased to about $-15^{\circ} \mathrm{C}$. The mixture was warmed to $10^{\circ} \mathrm{C}$ with stirring for $12 \mathrm{hr}$ and was then heated to $60^{\circ} \mathrm{C}$, as long as sulfur dioxide evolved. The direct vacuum distillation of this mixture yielded $399 \mathrm{~g}$ of 1,4-dichloro-2-butyne, bp $50^{\circ}$ to $70^{\circ} \mathrm{C}$ at $6.5 \mathrm{~mm} \mathrm{Hg}$ (yield, 70 percent).

(d) Halide for method $H$. The tetrabromide for this synthesis was made by addition of bromine to 1,5-hexadiene in several runs. In one of these, $800 \mathrm{ml}$ of chloroform and $490 \mathrm{~g}$ (6 moles) of 1,5hexadiene were added to a 5-liter 3-necked icecooled flask equipped with stirrer, addition vessel, and condenser. Approximately $0.98 \mathrm{~kg}$ (6 moles) of bromine was added slowly over a period of 2 $\mathrm{hr}$, followed by $100 \mathrm{ml}$ of additional chloroform and then by another charge of $0.98 \mathrm{~kg}$ ( 6 moles) of bromine. After the addition was complete, the mixture was filtered. The first crop of crystals weighed $517 \mathrm{~g}$; when the filtrate was cooled to $-20^{\circ} \mathrm{C}$, an additional $502 \mathrm{~g}$ of crystals were obtained in the second crop, and $228 \mathrm{~g}$ in the third. From four such runs, a total of $8,104 \mathrm{~g}$ of $1,2,5,6-$ tetrabromohexane was prepared, representing an over-all yield of 85 percent.

\subsection{Dehydrohalogenation Reactions}

Some of the dehydrohalogenations of dichlorides and of the chloroolefin to the corresponding acetylenes were carried out in the 50 -gal stainless-steel vessel. Table 6 lists some of the compounds prepared in this manner. The most convenient method of dehydrohalogenation utilized sodium amide suspended in refined light mineral oil at about $100^{\circ}$ to $150^{\circ} \mathrm{C}$ [2]. The technique employed in dehydrochlorinations in methods $\mathrm{E}$ and $\mathrm{F}$ is illustrated by the conversion of 1,1-dichloro-3-methylbutane to 3-methyl-1-butyne.

(a) Large-scale dehydrohalogenations in methods $E$ and $F$. The top of the condenser of the kettle was connected to another condenser kept at $-20^{\circ} \mathrm{C}$ and thence to a 5-liter trap at $-20^{\circ} \mathrm{C}$. To the 50 -gal stainless-steel kettle was added 26.5 liters of

\begin{tabular}{|c|c|c|c|c|c|c|c|c|}
\hline \multirow{2}{*}{ Hydrocarbon } & \multirow{2}{*}{$\begin{array}{l}\text { Syn- } \\
\text { thetic } \\
\text { method } \\
\text { (see } \\
\text { table } 3 \text { ) }\end{array}$} & \multicolumn{2}{|l|}{ Halide } & \multirow{2}{*}{$\begin{array}{l}\text { Sodium } \\
\text { amide }\end{array}$} & \multicolumn{2}{|c|}{$\begin{array}{l}\text { Dispersion } \\
\text { medium }\end{array}$} & \multirow{2}{*}{\multicolumn{2}{|c|}{ Yield }} \\
\hline & & Formula & $\begin{array}{l}\text { Quan- } \\
\text { tity }\end{array}$ & & $\begin{array}{l}\text { Vol- } \\
\text { ume }\end{array}$ & $\begin{array}{l}\text { Temper- } \\
\text { ature }\end{array}$ & & \\
\hline $\begin{array}{l}\text { 3-Methyl-1-butyne } \\
\text { 3-Methyl-1-pentyne } \\
\text { 3,3-Dimethyl-1-butyne } \\
\text { 4-Methyl-1-pentyne } \\
\text { 1,3-Butadiyne } \\
\text { 1,5-Hexadiyne }\end{array}$ & $\begin{array}{l}\mathrm{E} \\
\mathrm{E} \\
\mathrm{E} \\
\mathrm{F} \\
\mathrm{G} \\
\mathrm{H}\end{array}$ & $\begin{array}{l}\left(\mathrm{CH}_{3}\right)_{2} \mathrm{CHCH}_{2} \mathrm{CHCl}_{2} \\
\left.\mathrm{CH}_{3} \mathrm{CH}_{2} \mathrm{CH}_{2} \mathrm{CH}_{3}\right) \mathrm{CH}_{2} \mathrm{CHCl}_{2} \\
\left(\mathrm{CH}_{3}\right)_{3} \mathrm{CHH}_{2} \mathrm{CHCl}_{2} \\
\left(\mathrm{CH}_{3}\right)_{2} \mathrm{CHCH} \mathrm{CHCl}_{2} \mathrm{CCH} \mathrm{CH}_{2} \\
\mathrm{CH}_{2} \mathrm{ClC}=\mathrm{CCH}_{2} \mathrm{Cl} \\
\mathrm{CH}_{2} \mathrm{BrCHBrCH}{ }_{2} \mathrm{CH}_{2} \mathrm{CHBrCH}_{2} \mathrm{Br}\end{array}$ & $\begin{array}{c}\text { Moles } \\
80 \\
107 \\
60 \\
67.3 \\
\text { b1.5 } \\
\text { f } 6.6\end{array}$ & $\begin{array}{l}\text { Moles } \\
281 \\
375 \\
210 \\
168 \\
\text { с7. } 0 \\
58\end{array}$ & $\begin{array}{l}\text { Liters } \\
\text { a26.5 } \\
\text { a38 } \\
\text { a19 } \\
\text { a38 } \\
\text { d } 0.80 \\
\text { g17.5 }\end{array}$ & $\begin{array}{c}{ }^{\circ} \mathrm{C} \\
94 \\
100 \\
90 \text { to } 95 \\
140 \\
\text { e } 75 \\
-33\end{array}$ & $\begin{array}{l}\text { Moles } \\
49 \\
62.5 \\
28.5 \\
53.7 \\
0.9 \\
4.16\end{array}$ & $\begin{array}{l}\text { Percent } \\
62 \\
59 \\
45 \\
80 \\
60 \\
63\end{array}$ \\
\hline
\end{tabular}

TABLE 6. Hydrocarbons by dehydrohalogenation

aMineral oil. bDissolved in 1,200 g of $95 \%$ ethanol. cKOH. dWater. iDissolved in 7 liters of diethylether. gLiquid ammonia. 
light oil and $4.5 \mathrm{~kg}$ of sodium amide. The suspension was heated to $140^{\circ} \mathrm{C}$, and an initial $200 \mathrm{ml}$ of 1,1-dichloro-3-methylbutane was started to initiate the reaction; dehydrochlorination began immediately, as evidenced by the evolution of ammonia. The temperature of the suspension was reduced to $94^{\circ} \mathrm{C}$, and $3,630 \mathrm{~g}$ of the dihalide was added over a period of $3 \mathrm{hr}$. Ammonia was evolved during the entire course of the addition.

The next day, the contents of the kettle were cooled and an additional $6.36 \mathrm{~kg}$ of sodium amide was added to the pot (total 281 moles). Again the reaction mixture was heated to $94^{\circ} \mathrm{C}$, and the remainder of the dihalide, total $11.4 \mathrm{~kg}$ (80 moles), was added over a 7 -hr period. There was a continuous evolution of ammonia during the addition, and the reaction mixture assumed the consistency of a thick grease. The mixture was then heated for $48 \mathrm{hr}$, and it was noted that refluxing had ceased.

After cooling the reaction mixture, 7.5 liters of water was added cautiously with stirring. Only slight amounts of ammonia were evolved at this stage. Then there was added $3,500 \mathrm{ml}$ sulfuric acid (63 moles) in 95 liters of water. The reaction mixture was then distilled from the kettle until the distillate reached a temperature of $95^{\circ} \mathrm{C}$. The distillate was caught in isooctane, dried, and redistilled to recover $3.36 \mathrm{~kg}$ (49 moles) of 3-methyl-1butyne, bp $27^{\circ}$ to $32^{\circ} \mathrm{C}$, yield, 62 percent.

For the preparation of butadiyne and 1,5-hexadiyne, this method of dehydrohalogenation was not used; the data on these dehydrohalogenations are given in table 6 , and the description of the syntheses of these compounds are given below. Because of the ease of polymerization and peroxidation of these compounds, the syntheses and purifications were conducted in an inert atmosphere, and the final products sealed under their own vapor pressure.

(b) Dehydrochlorination in method $G$. The starting material for the synthesis of 1,3-butadiyne was 1,4dihydroxy-2-butyne [14] purchased from a commercial source. This alcohol was converted to 1,4dichloro-2-butyne [5], as described in section 3.4(c). The dichloride was converted to butadiyne by reaction with potassium hydroxide [7]. To a solution of $195 \mathrm{~g}$ of 1,4-dichloro-2-butyne in 1,200 $\mathrm{g}$ of 95 -percent ethanol at $75^{\circ} \mathrm{C}$ was added with stirring a solution of $400 \mathrm{~g}$ of potassium hydroxide and $800 \mathrm{~g}$ of water. The evolved 1,3-butadiyne was scrubbed with dilute potassium hydroxide and dried with calcium chloride. The yield in this step was 60 percent. The product from several such runs was fractionated in still 28. Mass-spectrometer analysis of the center cut indicated this distillate to be 99.8 percent pure.

(c) Dehydrobromination in method $H$. 1,5-Hexadiyne was obtained from the dehydrobromination of 1,2,5,6-tetrabromohexane with sodium amide in liquid ammonia.

As a starting material for this synthesis, large quantities of 1,5-hexadiene were prepared in the stainless-steel reactor in two identical runs. One of these is described below.

To $2.83 \mathrm{~kg}$ (118 moles) of magnesium in the kettle was added 3 liters of a solution prepared by mixing $15.2 \mathrm{~kg}$ (200 moles) of allyl chloride and 60 liters of ether. After reaction had started, 20 liters of ether and the remainder of the allyl chloride-ether mixture were added while the kettle jacket was keptcold. The reaction was not a very violent one, but as the addition proceeded, the mixture thickened considerably and became milky-white. Stirring was continued for 3 days; the mixture was then treated with 49 liters of water and about $3.6 \mathrm{~kg}$ of hydrochloric acid. The ether layer was washed three times with water and dried over anhydrous sodium carbonate. The products of two such runs were combined and distilled in column 6 to give $11.31 \mathrm{~kg}$ (138 moles) diallyl boiling $56^{\circ}$ to $63^{\circ} \mathrm{C}$. This recovery corresponds to a 69 -percent yield.

The 1,5-hexadiene was converted to the tetrabromide by treatment with bromine, as described in section $3.4(d)$; the 1,2,5,6-tetrabromohexane was then converted to 1,5-hexadiyne by an adaptation of the method of Raphael and Sandheimer [13]. One of the four dehydrobrominations is described.

To $12 \mathrm{~kg}$ of liquid ammonia in the 10-gal stainlesssteel kettle was added $2.27 \mathrm{~kg}$ (58 moles) of powdered sodium amide. To this stirred solution was added $2.63 \mathrm{~kg}$ (6.6 moles) of 1,2,5,6-tetrabromohexane dissolved in 7 liters of ether, and the solution stirred for 2 days. During this period the dry-ice condenser was allowed to warm up, permitting some of the ammonia to boil off. At the end of this time the reaction mixture was treated with 20 moles of ammonium chloride and 15 liters of water. The organic layer was siphoned, washed three times with water, and dried over anhydrous sodium carbonate. After the bulk of the ether had been stripped, the organic layer was distilled in column 19, and $313 \mathrm{~g}$ of a fraction boiling $86^{\circ}$ to $88^{\circ} \mathrm{C}$ was obtained, along with a forerun boiling $50^{\circ}$ to $86^{\circ} \mathrm{C}$. The total yield was 63 percent. Continued distillation past $90^{\circ} \mathrm{C}$ resulted in an explosion. The combined yield (bp $80^{\circ}$ to $88^{\circ}$ C) from four such runs was redistilled in column 19 , under a nitrogen atmosphere, to give the material with the properties listed in table 1 for this diacetylene.

\subsection{Miscellaneous Reactions - Method I}

The reactions illustrated by method I in table 3 were used for the preparation of 1-pentyne-3-ene. Because of its reactivity, the compound was sealed in the absence of air.

(a) 1-Pentyne-3-ene. This compound was prepared by treating the $p$-toluenesulfonate of l-pentyne4-ol with potassium hydroxide [3]. The l-pentyne4-ol was prepared by reacting propylene oxide with monosodium acetylide [8].

Sodium acetylide was prepared in the usual manner from 1,172 $\mathrm{g}$ of sodium, $15 \mathrm{~g}$ of ferric chloride, and $1.36 \mathrm{~kg}$ of acetylene in $10 \mathrm{ky}$ of liquid ammonia. To this was added $2,500 \mathrm{~g}$ (43 moles) of propylene oxide, and the mixture was stirred all night. The ammonia was allowed to evaporate, and 6 liters of water were added slowly. The reaction mixture was transferred to a glass vessel, made slightly acid 
with acetic acid, and steam distilled. The distillate was saturated with potassium carbonate and the organic layer separated, dried, and distilled. The portion boiling at $127.3^{\circ}$ to $127.5^{\circ} \mathrm{C}$ was collected as 1-pentyne-4-ol. The yield was 1,377 g (38 percent). A solution of $1,656 \mathrm{~g}$ of $p$-toluenesulfonyl chloride in $1,120 \mathrm{ml}$ of warm pyridine was cooled rapidly to obtain small crystals. To this slurry was added slowly $675 \mathrm{~g}$ (8.05 moles) of 1-pentyne-4-ol. The solution was well stirred and the temperature kept below $30^{\circ} \mathrm{C}$ with external cooling. After the vigor of the reaction had subsided, it was allowed to stand at room temperature for $20 \mathrm{hr}$, after which 1 liter of water was added with cooling. The reaction mixture was extracted with 2 liters of ether and the extract washed 4 times with 1.5 liters of 30 -percent sulfuric acid, 3 times with 1 liter of saturated sodiumbicarbonate solution, and, finally, 2 times with water and dried. The ether was removed by vacuum until a final pressure of $4 \mathrm{~mm} \mathrm{Hg}$ was reached. The yield was $1,876 \mathrm{~g}$ (98 percent).

To a stirred solution of $600 \mathrm{~g}$ of potassium hydroxide in 2 liters of water was added slowly 1,876 g (7.85 moles) of the $p$-toluene-sulfonate of l-pentyne4 -ol. The reaction temperature was kept at $110^{\circ} \mathrm{C}$, and a small amount of wetting agent was added to facilitate the reaction. The evolved vapors were collected in a trap at $-25^{\circ} \mathrm{C}$; the frozen distillate was melted periodically and the layers separated. The organic material amounted to $486 \mathrm{~g}$ (7.36 moles), representing a yield of 94 percent. This material was dried with calcium chloride and distilled in column 19. The distillation gave first a mixture of cis and trans forms (bp $43.8^{\circ}$ to $43.9^{\circ} \mathrm{C}, n_{D}{ }^{20}=1.4289$ to 1.4316 ) and then the pure trans form (bp $51.9^{\circ} \mathrm{C}$, $n_{D}{ }^{20}=1.4375$ ). Identification ${ }^{5}$ of the distillate fractions was made by infrared analysis, which demonstrated the presence of these two species and the absence of other isomers.

\subsection{Measurements of Physical Properties}

Because of the extremely reactive nature of several of the prepared compounds, final distillations of these were conducted from hydroquinone under a nitrogen atmosphere and bottled under their own vapor pressures [11]. This method of packaging reduced the amount of peroxides present and yielded samples suitable for physical-constants measurements. In general, the properties of the hydrocarbons measured included melting point or triple point, boiling point, refractive index, and density. The methods and techniques used in these determinations have been given previously [12].

Where feasible, the purities of samples were measured by mass spectrometry, calorimetrically [4], or by freezing-curve analysis [16]. For a more

\footnotetext{
${ }^{5}$ Determined and interpreted by F. A. Smith and J. E. Stewart of the Bureau's Gas Chemistry Section.
}

complete characterization of some of the l-acetylenes, mercury derivatives of these hydrocarbons were prepared according to the directions of Johnson and McEwen [6]. The data obtained on some of the compounds are listed in table 1, which is a summary of data obtained on the several compounds prepared.

\section{Conclusions}

Seventeen acetylenes, 1 olefin-acetylene, and 2 diacetylenes have been prepared in high states of purity. Physical constants are reported for these compounds; where feasible, the purity of the compound was determined.

Grateful acknowledgment is made to E. A. Cadwallader, R. L. Alexander, J. A. Cogliano, J. Todorov, and E. H. Rich for their assistance in preparing some of the compounds made in this work.

We thank G. T. Furukawa of the Thermodynamics Section for making the low-temperature calorimeter measurements, and V. H. Dibeler and F. L. Mohler of the Mass Spectrometry Section for the massspectrograph determinations, and F. A. Smith and J. E. Stewart of the Gas Chemistry Section for the infrared-absorption data and their interpretation.

\section{References}

[1] P. Bauman, Chemische Werke Hüls, GMBH, Marl, Germany, private communication.

[2] M. Bourguel, Ann. Chim. [10] 3, 191, 325 (1925).

[3] G. Eglinton, and M. C. Whiting, J. Chem. Soc. 3650 (1950).

[4] G. T. Furukawa, D. C. Ginnings, R. E. MeCoskey, and R. A. Nelson, J. Research NBS 46, 195 (1951) RP2191.

[5] F. L. Howard, T. W. Mears, A. Fookson, P. Pomerantz, and D. B. Brooks, J. Research NBS 38, 365 (1947) RP1779.

[6] J. R. Johnson, and W. L. MeEwen, J. Am. Chem. Soc. 48, $469(1926)$.

[7] E. Keyssner, and E. Eichler, German Patent 740,637.

[8] O. R. Kreimeier, U. S. Patent 2106182.

[9] Lespieau, Bul. Soc. Chim. France [4] 29, 528 (1921).

[10] B. J. Mair, A. R. Glasgow, Jr., and F. D. Rossini, J. Research NBS $2 \%, 39$ (1941) RP1402.

[11] B. J. Mair, D. J. Termini, C. B. Willingham, and F. D. Rossini, J. Research NBS 37, 229 (1946) RP1744.

[12] T. W. Mears, A. Fookson, P. Pomerantz, E. H. Rich, C. S. Dussinger, and F. L. Howard, J. Research NBS 49, 229 (1950) RP2079.

[13] R. A. Raphael, and F. Sandheimer, J. Chem. Soc., 120 (1950).

[14] W. Reppe, A. Steinhofer, H. Spaenig, and K. Locher, U. S. Patent 2306969.

[15] L. Schmerling, J. Am. Chem. Soc. 68, 1650 (1946).

[16] Selected values of properties of hydrocarbons, NBS Circular $461(1947)$.

[17] H. Van Risseghem, Bul. Soc. Chim. Belg. 42, 229 (1933).

Washington, August 19, 1953. 